\title{
Synthesis and Structural Characterization of Pd(II) complexes derived from perimidine ligand and their in vitro antimicrobial studies
}

Mohammad Azam*a, Ismail Warad ${ }^{\mathrm{a}}$, Saud I. Al-Resayes ${ }^{\mathrm{a}}$, Nabil Alzaqri ${ }^{\mathrm{a}}$, Mohammad Rizwan Khan $^{\mathrm{a}}$, Raghavaiah Pallepogu ${ }^{\mathrm{b}}$, Sourabh Dwivedi ${ }^{\mathrm{c}}$, Javed Musarrat ${ }^{\mathrm{d}}$ and Mohammad Shakir ${ }^{\mathrm{e}}$

${ }^{a}$ Department of Chemistry, King Saud University, P. O. Box 2455, Riyadh 11451, KSA

${ }^{b}$ School of Chemistry, University of Hyderabad, Hyderabad 500046, India

${ }^{c}$ Department of Zoology, King Saud University, P. O. Box 2455, Riyadh 11451, KSA

${ }^{d}$ Department of Ag. Microbiology, Faculty of Agricultural Sciences, Aligarh Muslim University, Aligarh 202002 India

${ }^{e}$ Department of Chemistry, Aligarh Muslim University, Aligarh 202002 India

For correspondence: Email:azam_res@yahoo.com, Tel: +966596441517

\section{Abstract:}

A novel series of $\mathrm{Pd}(\mathrm{II})$ complexes derived from 2-thiophenecarboxaldehyde and 1,8diaminonaphthalene has been synthesized and characterized by various physico-chemical and spectroscopic techniques viz., elemental analyses, IR, UV-Vis, ${ }^{1} \mathrm{H}$ and ${ }^{13} \mathrm{C}$ NMR spectroscopy, and ESI-mass spectrometry. The structure of ligand, 2-(2-thienyl)-2,3-dihydro-1H-perimidine 
has been ascertained on the basis of single crystal X-Ray diffraction. All Pd(II) complexes together with the corresponding ligand have been evaluated for their ability to suppress the in vitro growth of microbes, E. coli, S. aureus, P. aeruginosa, Citrobacter sp., B. subtilis and $S$. acidaminiphila and results show that Pd(II) complexes have more significant antimicrobial activity than their corresponding ligand. Fluorescence spectroscopic measurements clearly support that both of the Pd(II) complexes show significant DNA binding with calf thymus DNA.

Keywords: Heterocyclic compound, X-Ray structure of perimidine ligand, Pd(II) complexes, Antimicrobial activity

\section{Introduction:}

In recent years, the interest in coordination chemistry has been increasing continuously with the synthesis and characterization of a large number of transition metal complexes with heterocyclic systems (cyclic and acyclic) containing nitrogen, oxygen, and sulphur donor atoms because of 
their wide applications in various fields viz., pharmaceutical drugs, biological activities, efficient plant protection, analyzing reagents for trace and ultra trace heavy metal determination and preconcentration in aqueous media etc. [1-4]. Among heterocycles, perimidine and its derivatives have received considerable attention as they have high $\pi$ stacking ability, electron affinity, and reduction potential, and also exhibit diverse range of biological activities for example their potential to act as an anti-tumor, antiulcer, anti-malarial, and anti-fungal agents. Their biological activity is probably because of the presence of a perimidene ring system in nucleic acids, vitamins, co-enzymes and antibiotics [5-8]. The development of antimicrobial drugs to treat infectious diseases caused by the pathogens has been one of the most notable achievements of the past century. Despite the major breakthrough in modern medicine during the past 10 decades, the successful treatment towards multidrug-resistant pathogens (i.e., microbial isolates such as fungi and bacteria) has become a serious problem and remains a significant challenge over the last 10 years. Therefore, In spite of a large number of antibiotics and chemotherapeutics available for medical use, the antimicrobial resistance has created a substantial need for the development of new classes of antimicrobials that may not be as susceptible to the bacterial mechanism of resistance developed against the current range of drugs [9-12]. In continuation of our ongoing interest in chemistry of perimidine and its complexes [13], we, herein, report the synthesis, characterization and crystal structure of 2-(2-thienyl)-2,3-dihydro-1H-perimidine derived from 1,8-diaminonaphthalene and 2-thiophenecarboxaldehyde and its $\mathrm{Pd}(\mathrm{II})$ complexes followed by their in vitro antimicrobial and DNA interactive studies. Although various 2substituted 2,3-dihydro-1H-perimidines have been reported in literature [14]. No one, to the best of our knowledge, so far has reported the crystal structure of ligand, 2-(2-thienyl) 2,3-dihydro1H-perimidine. Therefore, to add the novelty in the work, we have successfully isolated the 
crystal of ligand, 2-(2-thienyl)-2,3-dihydro-1H-perimidine and its $\mathrm{Pd}(\mathrm{II})$ complexes followed by their in vitro antimicrobial activity.

\section{Experimental:}

\subsection{Materials and Methods}

All the reagents used were of analAR grade and were purchased from Merck and used as received.

Elemental analyses were recorded on a Elementar Varrio EL analyzer. ${ }^{1} \mathrm{H}$ and ${ }^{13} \mathrm{C}$ NMR spectra of ligand and its $\mathrm{Pd}(\mathrm{II})$ complexes were recorded in $\mathrm{CDCl}_{3}$ using JEOL 400 spectrometer. FT-IR $\left(4000-400 \mathrm{~cm}^{-1}\right)$ spectra were recorded as $\mathrm{KBr}$ pellet on a Perkin Elmer 621 spectrophotometer. Mass spectrometry was performed with a Micromass Quattro Premier tandem MS fitted with an ESI interface and controlled by MassLynx 4.1 software. MS/MS detection was performed with electrospray positive ionization mode. Electronic spectra of the complexes were obtained in dichloromethane on Pharmacia LKB-Biochem, UV-vis spectrophotometer at room temperature. Fluorescence measurements were performed on a spectrofluorimeter Model RF-540 (Shimadzu, Japan) equipped with a $150 \mathrm{~W}$ Xenon lamp and a slit width of $5 \mathrm{~nm}$.

\subsection{Synthesis of 2-(2-thienyl)2,3-dihydro-1H-perimidine, $L$}

A methanolic solution of 2-thiophenecarboxaldehyde $(1 \mathrm{mmol})$ was added dropwise to the methanolic solution of 1,8-diaminonaphthalene $(1 \mathrm{mmol})$. The reaction mixture was refluxed for $2 \mathrm{~h}$ resulting into a clear brown colored solution. The resulting colored solution was concentrated to $1 \mathrm{ml}$ followed by addition of $10 \mathrm{ml}$ hexane to cause precipitation. Precipitate was isolated and recrystallised in dichloromethane-n-hexane mixture. After few days, yellow crystals suitable for X-Ray diffraction appeared. 
Yield $65 \%$, Color: Yellow, Mp.: $138{ }^{0} \mathrm{C}$; Molecular formula C15H12N2S; ${ }^{1} \mathrm{H}$ NMR $\left(\mathrm{CDCl}_{3}\right): \delta$ (ppm) $3.35(\mathrm{NH}), 5.70(-\mathrm{CH}), 6.48-7.00(\mathrm{~m}, \mathrm{Ar}-\mathrm{H}), 7.13-7.27$ (m thiophene protons), ${ }^{13} \mathrm{C}$ NMR $\left(\mathrm{CDCl}_{3}\right): \delta(\mathrm{ppm}) 61.58(-\mathrm{CH}), 142.73(\mathrm{~N}-\mathrm{CH})$ Anal. Cal: C, 71.4; H, 4.79; N, 11.1; S, $12.7 \%$ Found: C, 71.35; H, 4.72; N, 11.05; S, $12.63 \%$ IR, $3320 \mathrm{~cm}^{-1}\left(v_{\mathrm{NH}}\right), 840 \mathrm{~cm}^{-1}\left(\mathrm{v}_{\mathrm{C}-\mathrm{S}-\mathrm{C}}\right)$ 2.3 Synthesis of complexes, [PdLCl 2$] 1$ and [PdL $\left.\left(\mathrm{OCOCH}_{3}\right)_{2}\right] \mathbf{2}$

A solution of $\mathrm{Pd}(\mathrm{II})$ salt $(0.50 \mathrm{mmol})$ dissolved in $15 \mathrm{ml}$ dichloromethane was added dropwise into $10 \mathrm{ml}$ dichloromethane solution of ligand $(0.50 \mathrm{mmol})$. The resultant reaction mixture was stirred for half an hour resulting into a clear yellow colored solution. The resulting solution was concentrated to $1 \mathrm{ml}$ followed by addition of $10 \mathrm{ml}$ of hexane to cause precipitation. The resulting yellow colored precipitate was isolated and recrystallised in dichloromethane-n-hexane and obtained in analytically pure form. No crystal was found suitable for single crystal XRD.

1: Yield: $62 \%$, Color: Yellow, Mp: $235{ }^{\circ} \mathrm{C}$, Molecular formula C15H12N2SPdCl2; ${ }^{1} \mathrm{H}$ NMR $\left(\mathrm{CDCl}_{3}\right): \delta(\mathrm{ppm}) 4.58(\mathrm{NH}), 5.75(\mathrm{CH}), 6.51-7.21(\mathrm{~m}, \mathrm{Ar}-\mathrm{H})$, 7.32-7.75 (m thiophene protons), ${ }^{13} \mathrm{C}$ NMR $\left(\mathrm{CDCl}_{3}\right): \delta(\mathrm{ppm})$ 63.81, $144.13(\mathrm{~N}-\mathrm{CH})$ Anal: Cal, C, 41.93; H, 2.81; N, 6.52; S, 7.46; Cl, 16.50; Pd, 24.76, Found, C, 41.85; H, 2.75; N, 6.47; S, 7.39; Cl, 16.43; Pd, 24.69, IR, $3310 \mathrm{~cm}^{-1}\left(v_{\mathrm{NH}}\right), 822 \mathrm{~cm}^{-1}\left(v_{\mathrm{C}-\mathrm{S}-\mathrm{C}}\right), 340 \mathrm{~cm}^{-1}\left(v_{\mathrm{Pd}-\mathrm{Cl}}\right), \mathrm{UV}$-vis $(\mathrm{nm}), 348,293,251$

2: Yield: $58 \%$, Color: Orange, Mp. $242{ }^{\circ} \mathrm{C}$, Molecular formula C19H18N2SO4Pd; ${ }^{1} \mathrm{H}$ NMR $\left(\mathrm{CDCl}_{3}\right): \delta(\mathrm{ppm}) 3.65(\mathrm{NH}), 5.69(\mathrm{CH}), 7.11-7.58(\mathrm{~m}, \mathrm{Ar}-\mathrm{H})$, 7.60-7.72 (m thiophene protons), ${ }^{13} \mathrm{C} \mathrm{NMR}\left(\mathrm{CDCl}_{3}\right): \delta(\mathrm{ppm}) 62.85(-\mathrm{CH}), 144.11(\mathrm{~N}-\mathrm{CH}), 52.55\left(-\mathrm{OCH}_{3}\right)$ Anal $\mathrm{Cal} ; \mathrm{C}, 47.85 ;$ H, 3.80; N, 5.88; O, 13.42; S,6.72, Pd, 22.31, Found, C, 47.81; H, 3.75; N, 5.81; O, 13.38; S, 6.67; Pd, 22.25, IR, $3315 \mathrm{~cm}^{-1}\left(v_{\mathrm{NH}}\right), 828 \mathrm{~cm}^{-1}\left(v_{\mathrm{C}-\mathrm{S}-\mathrm{C}}\right), \mathrm{UV}$-vis $(\mathrm{nm}), 345,291,250$. 2.4 Antimicrobial activity assay of ligand, $L$ and its $P d(I I)$ complexes 
The antimicrobial effect of ligand and its complexes was assessed against a variety of microbes including Escherichia coli, Staphylococcus aureus, Pseudomonas aeruginosa, Citrobacter sp., Bacillus subtilis and Stenotrophomonas acidaminiphila employing agar diffusion technique as reported in literature [15]. In brief, freshly grown bacterial cultures $\left(1.0 \times 10^{8} \mathrm{CFUml}^{-1}\right)$ were plated on nutrient agar plates. Wells ( $3 \mathrm{~mm}$ diameter) were cut in the agar plate and $50 \mu \mathrm{l}$ of compound $\left(100 \mu \mathrm{gwell}^{-1}\right)$ was dispensed in the centre of each well. DMSO (5\%) was used as a control. The plates were incubated at $37{ }^{\circ} \mathrm{C}$ for $24 \mathrm{~h}$ and the zones of inhibition were observed and documented. For quantitative estimation of the antimicrobial activity, the cells from the Gram negative (E. coli $\mathrm{AB}$ 1157) and Gram positive (Bacillus subtilis) bacterial strains were harvested in the exponential growth phase and the pellets were suspended in Tris-Cl buffer, $\mathrm{pH}$ 7.4. The cells were treated with increasing concentrations ( 0 to $100 \mu \mathrm{gml}^{-1}$ ) of ligand and its $\operatorname{Pd}(\mathrm{II})$ complexes, and incubated at $37^{\circ} \mathrm{C}$ for $6 \mathrm{~h}$. Subsequently, the cells were centrifuged and pellet were suspended in Tris- $\mathrm{Cl}$ buffer, $\mathrm{pH}$ 7.4. The treated cells along with untreated control were serially diluted and plated on nutrient agar plates to assay the colony forming ability. Plates were incubated overnight at $37^{\circ} \mathrm{C}$ and the colonies were counted. The percentage survival was determined and plotted as a function of concentration. Minimum inhibitory concentrations (MICs) were determined by broth dilution technique. The nutrient broth containing test compounds and controls were inoculated within approximately $1.0 \times 10^{8} \mathrm{CFUml}^{-1}$ of actively dividing bacteria cells. The cultures were incubated for $24 \mathrm{~h}$ at $37{ }^{\circ} \mathrm{C}$ and the growth was monitored visually and spectrophotometrically.

\subsection{Single crystal X-Ray diffraction analysis}


Single crystal X-ray data were collected on a Bruker SMART APEX CCD area detector system $[\lambda(\mathrm{Mo}-\mathrm{K} \alpha)=0.71073 \AA]$ at $291 \mathrm{~K}$, graphite monochromator with a $\omega$ scan width of $0.3^{\circ}$, crystaldetector distance $60 \mathrm{~mm}$, collimator $0.5 \mathrm{~mm}$. The SMART software was used for the intensity data acquisition and the SAINTPLUS Software was used for the data extraction [16]. Absorption correction and an empirical absorption correction using equivalent reflections were performed with the help of SADABS program [17]. The structure solution and full-matrix least-squares refinement against $\mathrm{F}^{2}$ were carried out using SHELXL-97 [18]. All non-hydrogen atoms were refined anisotropically.

\subsection{DNA binding assays of ligand, L and complexes 1 and 2}

DNA binding experiments were carried out using fluorescence spectrofluorometry. The purity of calf thymus DNA was confirmed by taking the ratio of the absorbance values at 260 and $280 \mathrm{~nm}$ in tris-EDTA (10 mM, pH 7.0) buffer, which was found to be $1.8: 1$, indicating that the DNA was sufficiently free of protein and other contaminants. For measurements, free ligand, L and its complexes 1 and 2 were dissolved in 2\% DMSO. DNA binding assays of synthesized compounds were carried out in the presence of ethidium bromide. DNA and ethidium bromide (EtBr) were dissolved in tris-EDTA (10 mM, pH 7.0) buffer at concentrations of 4 and $1 \mu \mathrm{g} \mathrm{ml}^{-1}$, respectively. The concentration of ligand, $\mathrm{L}$ and complexes 1 and 2 were $50 \mu \mathrm{M}$. To perform the experiments, DNA was pretreated with EtBr for $30 \mathrm{~min}$. Then the test solutions were added to this mixture of EtBr-DNA, and the change in the fluorescence intensity was measured. The fluorescence was recorded at $485-685 \mathrm{~nm}$ after exciting the solution at $478 \mathrm{~nm}$. The slits were set at $5 \mathrm{~nm}$ for excitation and emission. The path length of the sample was $1 \mathrm{~cm}$. To determine the DNA-binding ability of free ligand, $\mathrm{L}$ and complexes $\mathbf{1}$ and 2, fluorescence intensity data were analyzed by the Stern-Volmer equation [19]: 


$$
\mathrm{F}_{0} / \mathrm{F}=1+\mathrm{K}_{\mathrm{sv}}[\mathrm{Q}]
$$

where, $\mathrm{F}$ and $\mathrm{F}_{0}$ are the fluorescence intensity with and without the quencher (complex-DNA), $\mathrm{K}_{\mathrm{sv}}$ is the Stern-Volmer quenching constant, and [Q] is the concentration of the quencher.

\section{Result and Discussion:}

The perimidene ligand, $L$ has been synthesized by the reaction of 2-thiophenecarboxaldehyde and 1,8-diaminonaphthalene in 1:1 molar ratio in methanolic medium (Scheme). Its mononuclear $\mathrm{Pd}(\mathrm{II})$ complexes were synthesized by reaction of ligand, $\mathrm{L}$ and $\mathrm{Pd}(\mathrm{II})$ salts in 1:1 molar ratio in dichloromethane (Scheme). The analytical data agree well with the proposed composition of ligand and its complexes. The formation of ligand, L and its $\mathrm{Pd}(\mathrm{II})$ complexes was confirmed on the basis of results of elemental analyses, molecular ion peak in mass spectra, characteristic bands in FT-IR, and resonance signals in the ${ }^{1} \mathrm{H}$ and ${ }^{13} \mathrm{C}$ NMR spectra, and single crystal XRD in case of ligand. The geometry around Pd(II) ions in the complexes was confirmed from the positions of absorption bands observed in UV-vis spectra. Complexes so formed are consistently unstable in solution which can be explained by a coordination induced of the NH bond. This proton is easily removed in solution resulting in dissociation of the ligand from the metal. Over the last few decades, the Chemistry of organo palladium complexes has developed significantly. Literature has also revealed that organic moiety may undergo metallation with formation of carbon-metal bond by using transition metal complexes with two electron donor atoms. Cyclometallated complexes constitute an important tool to activate the $\mathrm{C}-\mathrm{H} \sigma$ bond stabilized by the additional coordination of metal to a heteroatom forming transition metal complexes [20-23]. $\mathrm{C}-\mathrm{H}$ functionalization has the potential to become a paradigm shifting for organic synthesis and over the last decade, a large variety of new $\mathrm{C}-\mathrm{H}$ functionalization methodologies have been 
developed [20-23]. The selective functionalization of $\mathrm{sp}^{3} \mathrm{C}-\mathrm{H}$ is challenging because $\mathrm{C}-\mathrm{H}$ bonds are unreactive and robust. Their low reactivity can be attributed to the fact that they are strong, localized, and unpolarized bonds. Transition metal catalysis can be used to assist in correcting C$\mathrm{H}$ bond to more reactive carbon-metal bonds that can subsequently be functionalized to afford the desired product. In most cases, the intramolecualr activation of the $\mathrm{C}-\mathrm{H}$ bond comes about with N-containing ligands, the metal quite often being palladium. The cyclopallaldated compounds formed thus way quite often display a characteristic ability as starting material in organic synthesis and have given way to wide slate of reaction which proceed with notable regio- and stereoselectivity, leading to extensive possibilities for synthetic applications [20-23]. The synthesized ligand, $\mathrm{L}$ and its $\mathrm{Pd}(\mathrm{II})$ complexes were tested in vito against a number of microbes and results showed complexes to be more effective as compared to their corresponding ligand, L. DNA interactive studies have also been carried out with CT-DNA and results suggest that Pd(II) complexes have significant DNA binding as compared to their corresponding ligand, L.

\subsection{IR Investigations}

The IR frequencies associated with the main functional group of the complexes are listed in the experimental section [Fig 1S]. The results obtained are in accordance with the proposed structures of the ligand and its $\operatorname{Pd}(\mathrm{II})$ complexes [14,24]. The IR spectrum of ligand exhibits a strong band at $3320 \mathrm{~cm}^{-1}$ assigned to -NH group which undergoes a negative shift $\mathrm{ca} .10 \mathrm{~cm}^{-1}$ in $\operatorname{Pd}(\mathrm{II})$ complexes indicating the coordination of ligand to $\mathrm{Pd}(\mathrm{II})$ ion [25]. The medium intensity band observed at $840 \mathrm{~cm}^{-1}$ in the free ligand assigned to $v_{\mathrm{C}-\mathrm{S}-\mathrm{C}}$ stretching vibration of thiophene moiety is shifted to lower values ca. $20 \mathrm{~cm}^{-1}$ in $\mathrm{Pd}$ (II) complexes, suggesting the involvement of 
the sulphur atom in bonding with $\mathrm{Pd}(\mathrm{II})$ ion [26]. The band assigned to the asymmetric $\mathrm{v}_{(\mathrm{C}-\mathrm{S})}$ observed at $630 \mathrm{~cm}^{-1}$ is shifted to lower frequency ca. $25 \mathrm{~cm}^{-1}$ in the complexes confirming the coordination of sulphur atom [27]. However, it is further confirmed in the far IR spectra by the appearance of new band at $240-280 \mathrm{~cm}^{-1}$ assignable to $\mathrm{Pd}-\mathrm{S}$ vibration [28]. IR spectra of Pd(II) complexes show bands at $340 \mathrm{~cm}^{-1}$ and $365 \mathrm{~cm}^{-1}$ assignable to $\mathrm{Pd}-\mathrm{Cl}$ band while the carboxylate bands in complex 2 appear at $1550 \mathrm{~cm}^{-1}[24,29]$.

\subsection{NMR investigations}

The ${ }^{1} \mathrm{H}$ and ${ }^{13} \mathrm{C}$ NMR spectra of ligand and its $\mathrm{Pd}(\mathrm{II})$ complexes provide their important structural information and the results obtained are in close agreement with those obtained by Xray and IR studies. The ${ }^{1} \mathrm{H}$ NMR spectrum of ligand shows a singlet at $3.35 \mathrm{ppm}(\mathrm{s}-\mathrm{NH})$ which undergoes downfield shift and appear at $4.58 \mathrm{ppm}$ and $3.68 \mathrm{ppm}$ in complex $\mathbf{1}$ and $\mathbf{2}$, respectively [28]. The aromatic protons of free ligand exhibit a multiplet in 6.48-7.0 ppm region [30], while the resonance signals corresponding to protons of thiophene moiety appeared in 7.13$7.27 \mathrm{ppm}$ region $(\mathrm{m}, 3 \mathrm{H})$ [Fig $2 \mathrm{~S}$ ] [31]. These valued were found to be shifted downfield and appear at 6.51-7.21 ppm (m, Ar-H) and 7.32-7.75 ppm (m thiophene protons) and 7.11-7.58 ppm $(\mathrm{m}, \mathrm{Ar}-\mathrm{H})$ and 7.60-7.72 ppm (m thiophene protons) in complex 1 and 2 , respectively [Fig $2 \mathrm{~S}$, 3S]. An additional signal corresponding to methyl proton of $-\mathrm{OCOCH}_{3}$ group was observed at $2.09 \mathrm{pm}$ in complex 2 [Fig 3S].

The ${ }^{13} \mathrm{C}$ NMR spectral findings further ascertain the ${ }^{1} \mathrm{H}$ NMR spectral data. The ${ }^{13} \mathrm{C}$ NMR spectrum of ligand shows characteristic sets of signals belonging to aliphatic and aromatic carbons [Fig 4S]. These values were deshielded upon complexation [Fig 5S, 6S]. A signal attributed to $-\mathrm{CH}_{3}$ of acetate group was observed at $52.55 \mathrm{ppm}$ in complex 2 [Fig 6S]. 


\subsection{Single crystal X-Ray diffraction studies}

2-(2-thienyl)2,3-dihydro-1H-perimidine crystallizes in the cetrosymmetric monoclinic $P 2{ }_{1} / c$ space group with all atoms located in general positions. The X-Ray crystal structure of ligand, 2(2-thienyl)2,3-dihydro-1H-perimidine shows two crystallographically independent 2-(2thienyl)2,3-dihydro-1H-perimidine in its asymmetric unit and there are four such units in the unit cell $(\mathrm{Z}=4)$ and the relevant parameters are tabulated in the Table 1S-5S. An ORTEP representation is shown in Fig 7S with atom labeling scheme used and a perspective view of packing pattern is shown in [Fig 1]. The observed $\mathrm{C}-\mathrm{C}, \mathrm{C}-\mathrm{N}$ and $\mathrm{C}-\mathrm{S}$ bond lengths as well as the bond angles of the molecule are in the normal range and are in good agreement with those observed for the corresponding compounds reported in the literature [32]. The $\mathrm{C}-\mathrm{S}$ bond lengths and bond angles are in the range from $1.642(5)$ to $1.715(3) \AA$ and $111.8^{\circ}$ to $123.7^{\circ}$, respectively. Interestingly $\mathrm{N}-\mathrm{H} \cdots \mathrm{N}$ hydrogen bonding interaction with $\mathrm{H}$ to $\mathrm{N}$ separation of $2.33 \AA$ is observed between N4 and N1 atoms [Fig 2] [Table 1].

\subsection{Mass spectrometry}

Mass spectra of the perimidene ligand $\mathrm{L}$ and its $\mathrm{Pd}(\mathrm{II})$ complexes exhibited molecular ion peak $[\mathrm{M}+\mathrm{H}]+, \mathrm{m} / \mathrm{z}$ at $253.39,430.67$, and 477.85 corresponding to their molecular formulae, [C15H12N2S], [C15H12N2SPdCl2], and [C19H18N2SO4Pd], respectively, as their calculated $m / z$ being $252.39,429.66$, and 476.85 for their corresponding compounds, [C15H12N2S], [C15H12N2SPdCl2], and [C19H18N2SO4Pd], respectively [Fig 3] [Fig 8S, 9S].

\subsection{Electronic spectra}


Electronic spectra of $\mathrm{Pd}(\mathrm{II})$ complexes have been recorded in $\mathrm{CH}_{2} \mathrm{Cl}_{2}$. Both the $\mathrm{Pd}(\mathrm{II})$ complexes, $\mathbf{1}$ and $\mathbf{2}$, are diamagnetic with square planar geometry, for which three spin- allowed d-d transitions are expected, corresponding to transitions from the three lower lying d-orbitals to the empty $d x^{2}-y^{2}$ orbitals [33]. The ground state is ${ }^{1} A_{2 g}$ and the excited states related to these transitions are ${ }^{1} \mathrm{~A}_{2 \mathrm{~g}},{ }^{1} \mathrm{~B}_{1 \mathrm{~g}}$ and ${ }^{1} \mathrm{E}_{\mathrm{g}}$ [34]. The most prominent absorption is around 348, 293 and $251 \mathrm{~nm}$ respectively, which could be assigned to metal-to-ligand charge-transfer transitions [Fig 10S] [35-37].

\subsection{Antimicrobial activity}

The antimicrobial effect of ligand and its Pd(II) complexes was assessed against a variety of microorganisms including Escherichia coli, Staphylococcus aureus, Pseudomonas aeruginosa, Citrobacter sp., Bacillus subtilis and Stenotrophomonas acidaminiphila. The minimum inhibitory concentration of ligand and its complexes was also determined against these six test bacterial strains by broth dilution technique [Table 2]. The activities of the compounds were compared with Amoxicillin, as a standard drug. Since DMSO was used as a solvent, it was also screened against all organisms and no activity was found. The complex $\mathbf{1}$ and complex $\mathbf{2}$ were the most active complexes inhibiting bacterial growth at $50 \mu \mathrm{gmL}^{-1}$ and $100 \mu \mathrm{gmL}^{-1}$, respectively as compared to positive control, amoxicillin which exhibited MIC upto $30 \mu \mathrm{gmL}^{-1}$. Thus confirms that our complexes show better antimicrobial activity as compared to reported palladium complexes $[38,39]$. All the tested compounds show lesser activity than the standard antibiotics. Treatment of cells with these compounds resulted in formation of the zones of inhibition of variable sizes in all the six tested bacterial strains [Fig 11S, 12S]. El-Sherif and coworkers have reported the higher activity of the complexes as compared to the free ligand which 
can further be understood in terms of the chelation theory. This theory explains that a decrease in the polarizability of the metal could enhance the lipophilicity of the complexes [38, 40]. comparative study revealed that complex 1 showed larger zones $(16-19 \mathrm{~mm})$ as compared to complex $2(9-12 \mathrm{~mm})$ which is larger as compared to ligand $(7-9 \mathrm{~mm})$ with all the tested strains. The growth inhibiting activity of the ligand and its complexes was further validated by measuring the reduction in survival of treated bacterial cells against the control. The results demonstrate greater antimicrobial activity of ligand and its $\mathrm{Pd}(\mathrm{II})$ complexes on E.coli cells vis-a vis Bacillus subtilis cells. The antibacterial potency was found to be in the order as complex $\mathbf{1}>$ complex $2>$ ligand, both in case of the Gram negative and Gram positive bacteria, in a concentration dependent manner. The \% reduction in the viability of E. coli and Bacillus subtilis was determined to be $88 \%, 70 \%$, and $60 \%$ and $75 \%, 62 \%$ and $49 \%$ with complex 1, complex 2 and ligand, respectively. The data explicitly suggested the differential antibacterial activity of the tested complexes which could be applied in the treatment of some common diseases e.g., gastroenteritis, urinary tract infections, and hospital-acquired infections [40, 41].

\subsection{Fluorescence measurements for DNA binding}

The fluorescence spectroscopy provides insight of the changes taken place in the microenvironment of DNA molecule on ligand binding. The binding of these compounds with calf thymus DNA was studied by monitoring the changes in the intrinsic fluorescence of these compounds at varying concentration of ligand and its complex. Fig 4 shows the representative fluorescence emission spectra of the EtBr-DNA complex. Ethidium bromide, a polycyclic aromatic dye, is the most widely used fluorescence probe for DNA structure. EtBr displays very weak fluorescence in aqueous solution. However, in the presence of DNA, it exhibits intense 
fluorescence because of intercalation with base pairs in DNA [42]. The addition of complexes caused a gradual decrease in the fluorescence emission intensity of EtBr-DNA complexes with a conspicuous change in the emission signals. The quenching of the compound fluorescence clearly indicated that the binding of DNA to Ligand and its complexes changed the microenvironment of fluorophore residue. Our results showed complexes 1 and 2 had a greater quenching effect as compared to free ligand L, thus indicating greater affinity of both the complexes when compared to the free ligand. The $\mathrm{K}_{\mathrm{Sv}}$ value of the complexes $(\mathrm{EtBr}+\mathrm{DNA}+$ $\mathrm{L}),(\mathrm{EtBr}+\mathrm{DNA}+1)$ and $(\mathrm{EtBr}+\mathrm{DNA}+2)$ were calculated to be $1.01 \times 10^{4}, 2.65 \times 10^{4}$ and 2.8 $\times 10^{4} \mathrm{M}^{-1}$, respectively. A higher $\mathrm{K}_{\mathrm{SV}}$ value of complex 1 and 2 suggests its stronger quenching ability than free ligand L. This difference in the DNA binding ability could be due to the presence of an electron deficient center in the charged $\mathrm{Pd}$ (II) complex where an additional interaction between the complex and phosphate rich DNA backbone may occur [43].

\section{Conclusion:}

A novel series of two Pd(II) complexes derived from 2-(2-thienyl)2,3-dihydro-1H-perimidine has been synthesized and structurally characterized. The spectral data are in consistent with the proposed structure of ligand and its $\mathrm{Pd}(\mathrm{II})$ complexes. Biological activities of the ligand, L and both of its complexes were examined by screening their ability to inhibit the growth of bacteria especially E.coli, S. aureus, P. aeruginosa, Citrobacter sp., B. subtilis and S. acidaminiphila Results suggested complex $\mathbf{1}$ to be more effective than its ligand and Complex $\mathbf{2}$ against E. coli and $B$. subtilis. DNA interactive studies with the synthesized compounds also suggest that $\mathrm{Pd}(\mathrm{II})$ complexes have more effective DNA binding as compared to the ligand.

\section{Supplementary material available:}


CCDC 823368 contains the supplementary crystallographic data for this paper. These data can be obtained free of charge from the Cambridge Crystallographic Data Centre via www.ccdc.cam.ac.uk./data request/cif.

\section{Acknowledgements:}

The project was supported by the Research Centre, College of Science, King Saud University, Riyadh. 


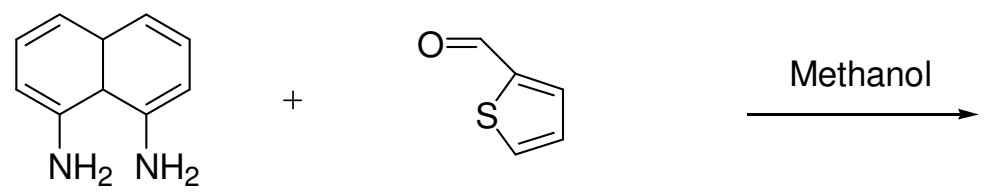<smiles>c1csc(C2Nc3cccc4cccc(c34)N2)c1</smiles>

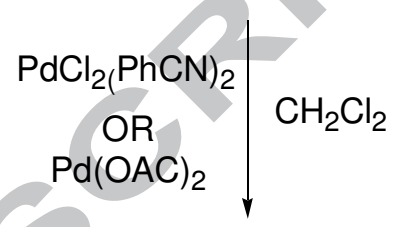

Scheme: synthetic route of the preparation of ligand, 2-(2-thienyl)2,3-dihydro-1H-perimidine and its $\mathrm{Pd}(\mathrm{II})$ complexes

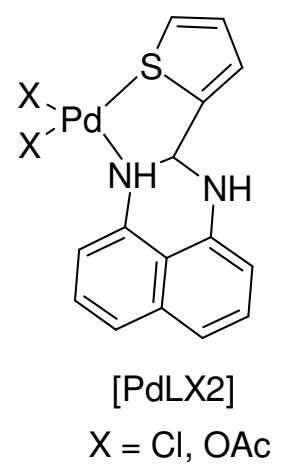




\section{References:}

[1]. X.-F. He, C.M. Vogels, A. Decken, S.A. Westcott, Polyhedron, 23 (2004) 155.

[2]. M. Massacesi, R. Pinna, M. Biddau, G. Ponticelli, I.A. Zakharova, Inorg. Chem. Acta, 80 (1983) 151.

[3]. I. Yalcin, I. Oren, E. Sener, A. Akin, N. Ucarturk, Eur. J. Med. Chem., 27 (1992) 401.

[4]. I. Yavari, H. Mostafavi, D. Tahmassebi, R.H.-Shoar, Monatsch chem., 128 (1997) 675.

[5]. G. Varsha, V. Arun, P.P. Robinson, M. Sebastian, D. Varghese, P. Leeju, V.P. Jayachanran, K.K.M. Yusuff, Tetrahedron Lett., 51 (2010) 2174.

[6]. M. Sonmez, M. Celebi, A. Levent, I. Berber, Z. Senturk, J. Coord. Chem., 63 (2010) 848.

[7]. J.A.S. Smellie, A. Fromm, R.M. Paton, Tetrahedron Lett., 50 (2009) 4104.

[8]. Y. Tokimizu, Y. Ohta, H. Chiba, S. Oishi, N. Fuji, H. Ohno, Tetrahedron, 67 (2011) 5168.

[9]. H.W. Boucher, G.H. Talbot, J.S. Bradley, J.E. Eswards Jr, D. Gilbert, L.B. Rice, M. Scheld, B. Spelberg, J. Barlett, IDSA Report on Development Pipeline. Clin. Infcet. Dis., 48 (2009) 1.

[10]. J. Travis, J. Potempa, Biochem. Biophys. Acta, 1477 (2000) 35.

[11]. Z. Zhang, W. Zhou, A. Yu, Bioorg. Med. Chem. Lett., 14 (2004) 393. 
[12]. F. Qadri, A.M. Svennerholm, A.S.G. Faruque, R.B. Sack, Clin. Microbiol. Rev., 18 (2005) 465.

[13]. M. Azam, I. warad, S. Al-Resayes, M. Zahin, I. Ahmad, M. Shakir, Z. Anorg. Allg. Chem., 638 (2012) 881.

[14]. W. Wasulko, A.C. Noble, F.D. Popp, J. Med. Chem., 9 (1966) 599.

[15]. J. Musarrat, S. Dwivedi , B.R. Singh , A. A. Al-Khedhairy , A. Azam , A. Naqvi, Bior. Techn., 101 (2010) 8772.

[16]. SMART V5.630 and SAINT-plus V6.45, Bruker-Nonius Analytical X-ray Systems Inc.: Madison, WI, 2003.

[17]. G.M. Sheldrick, SADABS, Program for Empirical Absorption Correction, University of Gottingen, Germany, 1996.

[18]. G.M. Sheldrick, Acta Crystallogr., A 64 (2008) 112.

[19]. A.M. Pyle, J.P. Rehmann, R. Meshoyrer, C.V. Kumar, N.J. Turro, J.K. Barton J. Am. Chem., Soc., 111 (1989) 3051.

[20]. B. Garcia, F.J. Hoyuelos, S. Ibeas. M.S. Munoz, A.M. Navarro, I.A. Panacoba, J.M. Leal, Chem. Asian J., 5 (2010) 2530.

[21]. B. Garcia, F.J. Hoyuelos, S. Ibeas. M.S. Munoz, A.M. Navarro, I.A. Panacoba, J.M. Leal, J. Phys. Chem. A, 113 (2009) 9115.

[22]. J.A. Labinger, J.E. Bercaw, Nature, 417 (2002) 507.

[23]. R.H. Crabtree, Chem. Rev., 85 (1985) 245.

[24]. G. Ponticelli, A. Spanu, Trans. Met. Chem., 24 (1999) 370-372. 
[25]. M. Juribasic, K. Molcanov, B.K.-Prodic, L. Bellotto, M. Kralj, F. Zani, L.T.-Bozic, J. Inorg. Biochem., 105 (2011) 867.

[26]. C. Spinu, A. Kriza, Acta Chim. Slov., 47 (2000) 179.

[27]. S. Chandra, R. Kumar, R. Singh, Spectrochim. Acta Part A, 65 (2006) 215.

[28]. M. Kumar Samota, G. Seth, Heteroatom Chem., 21 (2010) 44.

[29]. T. Ishioka, Y. Shibata, M. Takahashi, I. Kanesaka, Y. Kitagawa, K.T. Nakamura, Spectrochim. Acta Part A, 54 (1998) 1827.

[30]. S. Sharma, F. Ather, F.R. Maurya, A. Azam, Eur. J. Med. Chem., 40 (2005) 1414.

[31]. H.A. Jeong, E.J. Cho, H.M. Yeo, B.J. Ryu, K.C. Nam, Bull Korean Chem. Soc., 28 (2007) 851 .

[32]. G. Varsha, V. Arun, P. P. Robinson, Manju Sebastian, Digna Varghese, P. Leeju, V. P. Jayachandran, and K. K. M. Yusuff, Tetrahedron Lett., 51 (2010) 2174.

[33]. S.E Livingstone, The Chemistry of Ruthenium, Rhodium, Palladium, Osmium, Iridium and Platinum Complexes, Pergamon Press, Oxford, 1973.

[34]. Lj.T.-Bozic, A. Furlani, V.Scarcia, E.De Clercq, J. Balzarini, J.Inorg.Biochem., 72 (1998) 201.

[35]. A.B.P. Lever, Inorganic Electronic Spectroscopy, Elsevier, New York, 1984.

[36]. E. Alessio, G. Menstroni, A. Bergamo, G. Sava, Curr. Top. Med. Chem., 4 (2004) 1525. 
[37]. M.A. Jakupec, M. Galanski, V.B. Arion, C.G. Hartinger, B.K. Kepler, Dalton Trans., (2008) 183.

[38]. A. A. El-Sherif, J. Coord. Chem., 64 (2011) 2035.

[39]. F.R.G. Bergamini, C. Abbehausen, A. Magalhaes, W.R. Lustri, A.F. Gomes, F.C. Gozzo, P.P. Corbi, J. Coord. Chem., 64 (2011) 3092.

[40]. G. P. Radic', V. V. Glodovic', I. D. Radojevic', O. D. Stefanovic', Ljiljana R. Comic’,V. M. Dinovic, S. R. Trifunovic', Inorg. Chim. Acta, 391 (2012) 44.

[41]. E. Jawetz, J.L. Melnick, E.A. Adelberg. Review of Medical Microbiology, 6th Edn, Lang Medical Publications, Los Angeles, CA, 1979.

[42]. M. Azam, Z. Hussain, I. Warad, S. Al-Resayes, M.S. Khan, M. Shakir, A.T.Kruszynska, R. Kruszynski, Dalton Trans., 41 (2012) 10854.

[43]. J. Liu, T. Zhang, T. Lu, L. Qu, H. Zhou, Q. Zhang and L. Ji, J. Inorg. Biochem., 91 (2002) 269. 


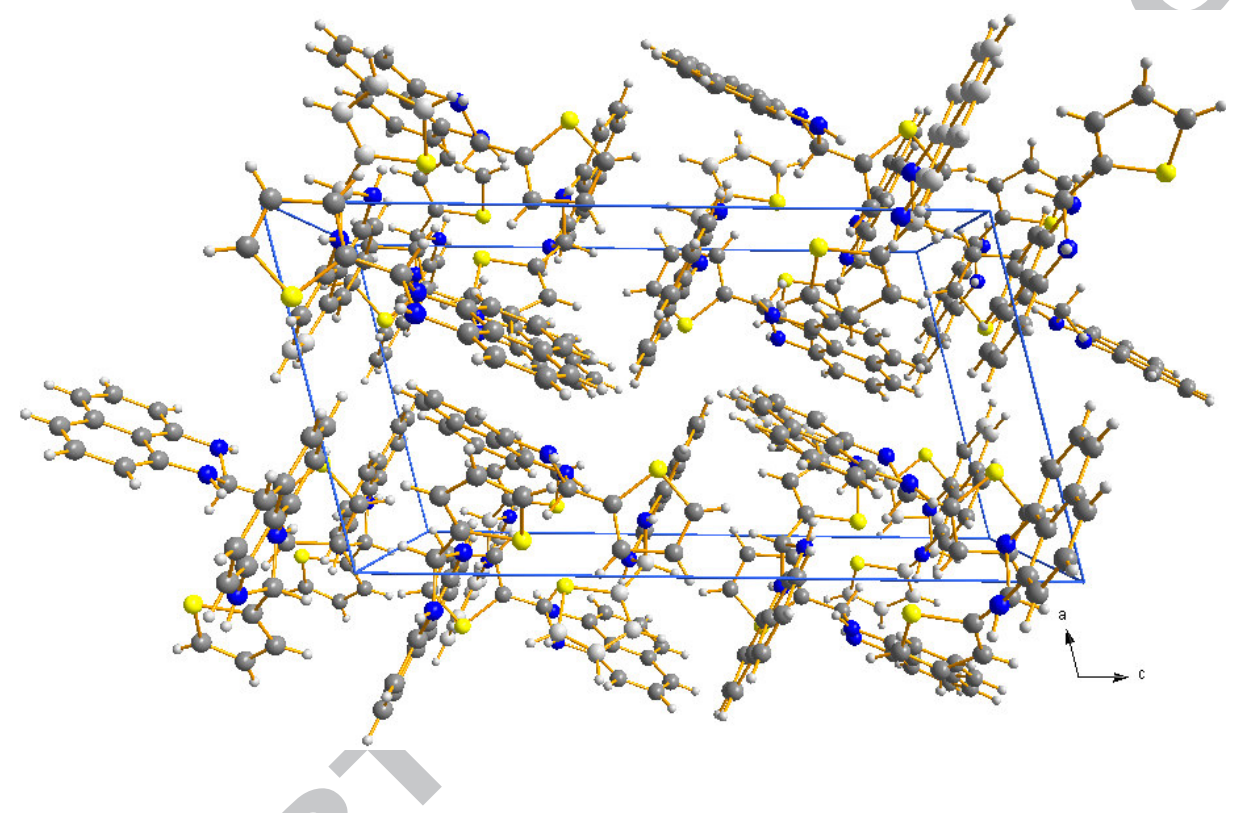

Fig 1: A crystal packing of 2-(2-thienyl)2,3-dihydro-1H-perimidine viewed (perspective) along crystallographic $b$ direction. 


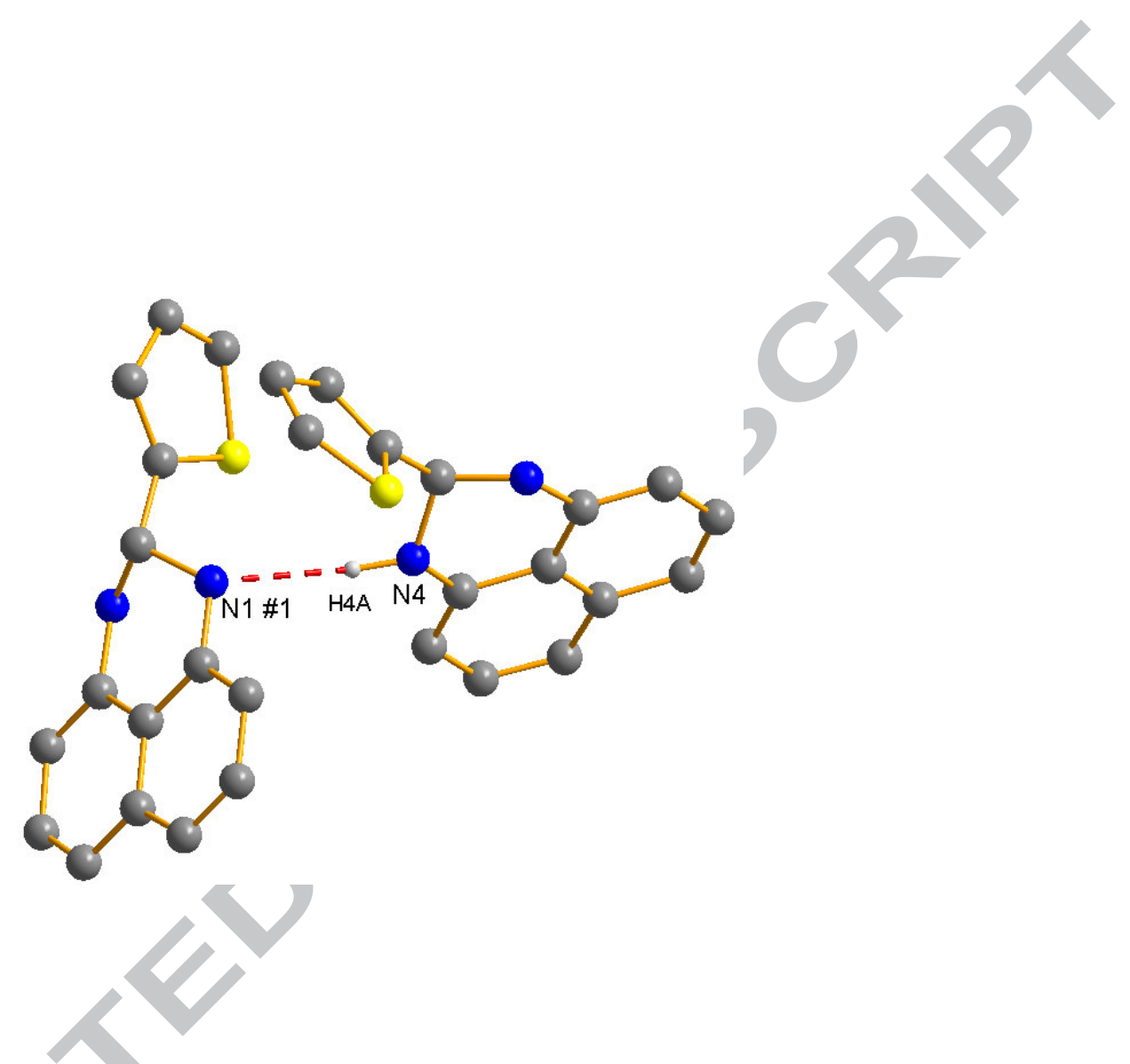

Fig 2: The Hydrogen bonding interactions with $\mathrm{H}$ to $\mathrm{N}$ separation of $2.33 \AA$ (shown as red dotted lines) between two molecules with asymmetric codes \#1: 1-x,-1/2+y,1/2-z . The other hydrogen atoms are omitted for clarity. 


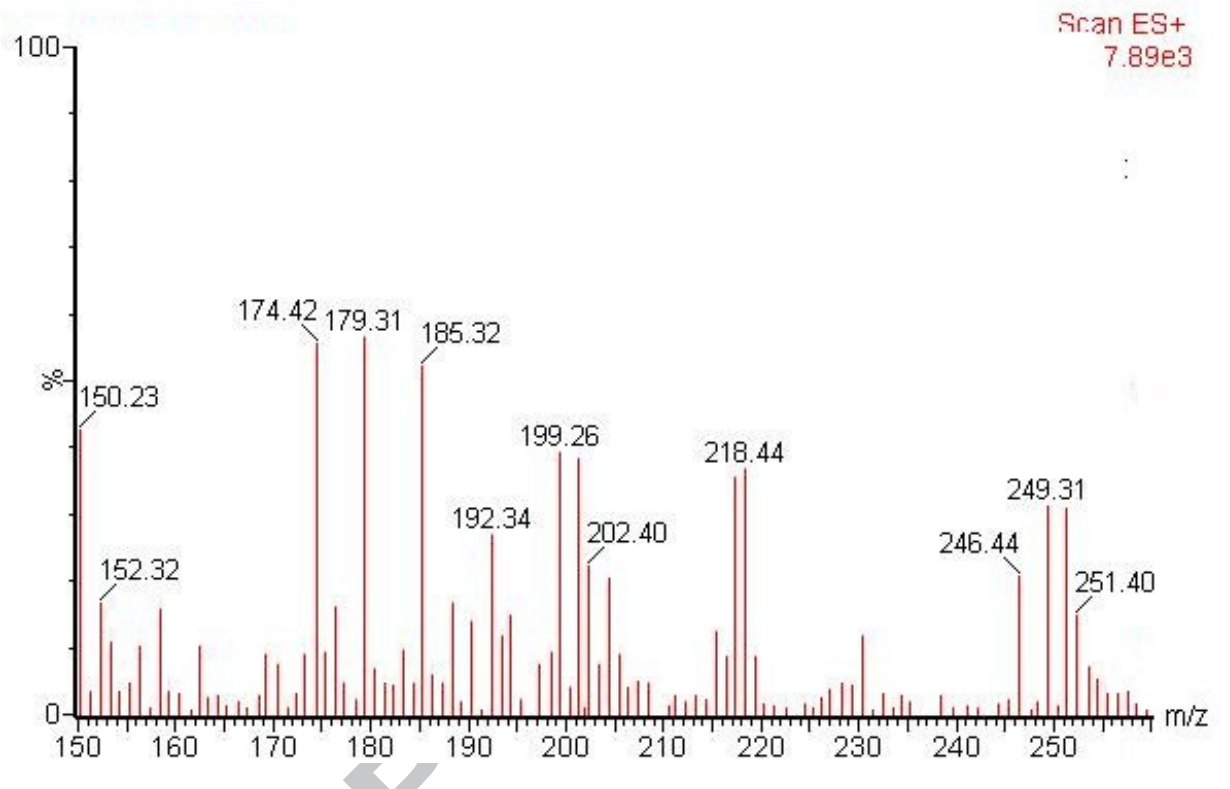

Fig 3: ESI-MS spectrum of ligand, L 


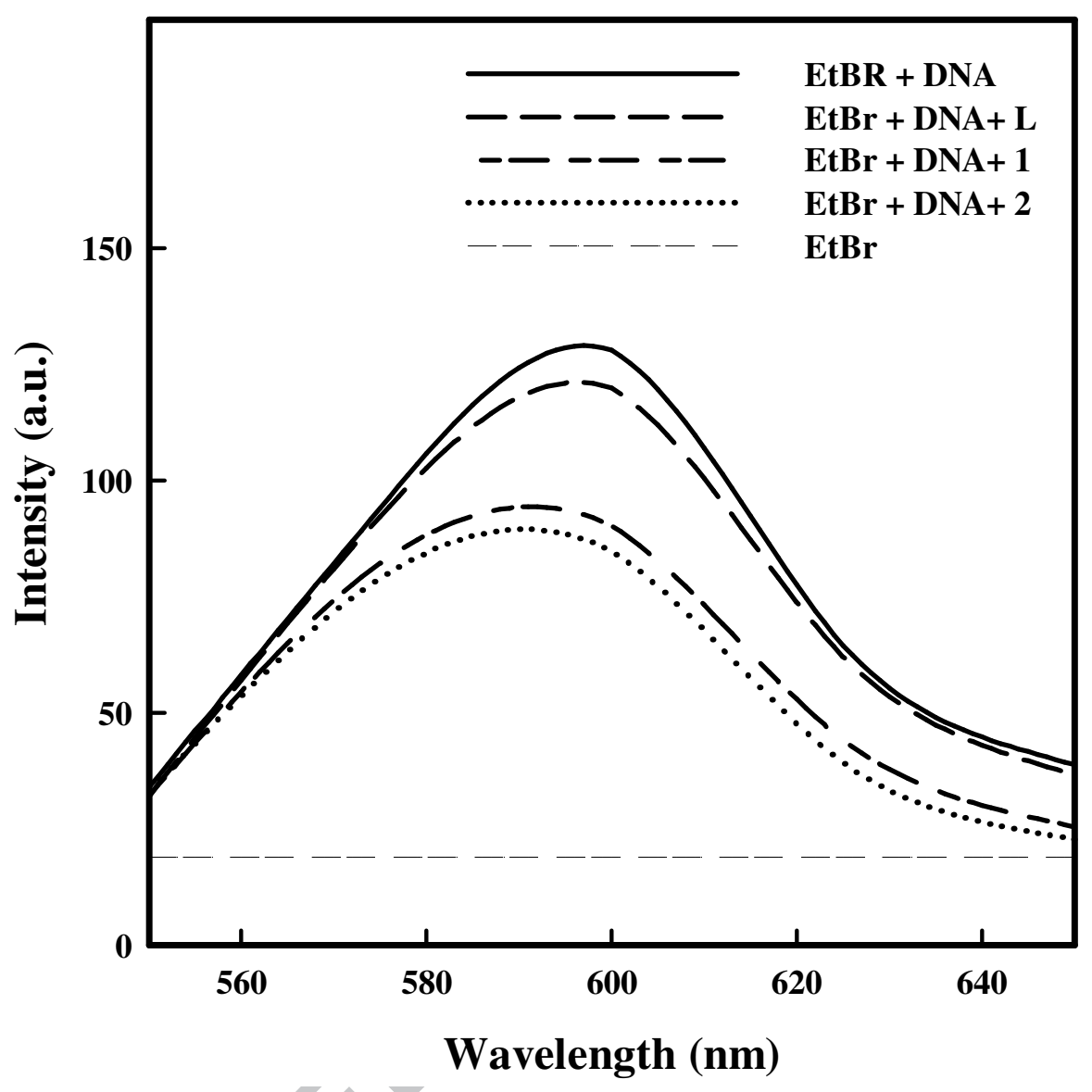

Fig 4: Fluorescence emission spectra of ethidium bromide (EB) bound to DNA in the absence and presence of ligand, L and complex 1 and complex 2. 
Table 1: Hydrogen bonding parameters ( $₫$, deg)

\begin{tabular}{lllll}
\hline $\mathrm{D}-\mathrm{H} \cdots \mathrm{A}$ & $d(\mathrm{D}-\mathrm{H})$ & $d(\mathrm{H} \cdots \mathrm{A})$ & $\mathrm{D}(\mathrm{D} \cdots \mathrm{A})$ & $\angle \mathrm{DHA}$ \\
\hline $\mathrm{N} 4-\mathrm{H} 4 \mathrm{~A} \cdots \mathrm{N} 1$ & $0.97(3)$ & $2.33(3)$ & $3.295(5)$ & $165.2(3)$ \\
\hline
\end{tabular}

Symmetry transformations used to generate equivalent atoms: \#1: 1-x,-1/2+y,1/2-z. 
Table 2: MICs $\left(\mu \mathrm{gml}^{-1}\right)$ of tested bacterial strains

\begin{tabular}{lcccc}
\hline \multirow{2}{*}{ Bacterial strains } & & & MIC $\left(\boldsymbol{\mu g m l}^{-1}\right)$ & Amoxicillin \\
\cline { 2 - 5 } & Ligand & Complex 1 & Complex 2 & 30 \\
\hline Escherichia coli & 100 & 50 & 100 & 30 \\
Staphylococcus aureus & 100 & 50 & 75 & 30 \\
Pseudomonas aeruginosa & 100 & 50 & 100 & 30 \\
Citrobacter sp. & 75 & 50 & 75 & 30 \\
Bacillus subtilis & 50 & 40 & 70 & 30 \\
$\begin{array}{l}\text { Stenotrophomonas } \\
\text { acidaminiphila }\end{array}$ & 75 & 30 & 75 & 30 \\
\hline
\end{tabular}


1.

2.

crystallography

3.

4. more effective inhibitor of microbial growth
Synthesis and characterization of perimidine ligand

Structure of ligand ascertained on the basis of X-ray

Complexes characterized by various spectroscopic studies

In vitro anti microbial screening showed $\mathrm{Pd}(\mathrm{II})$ complexes to be

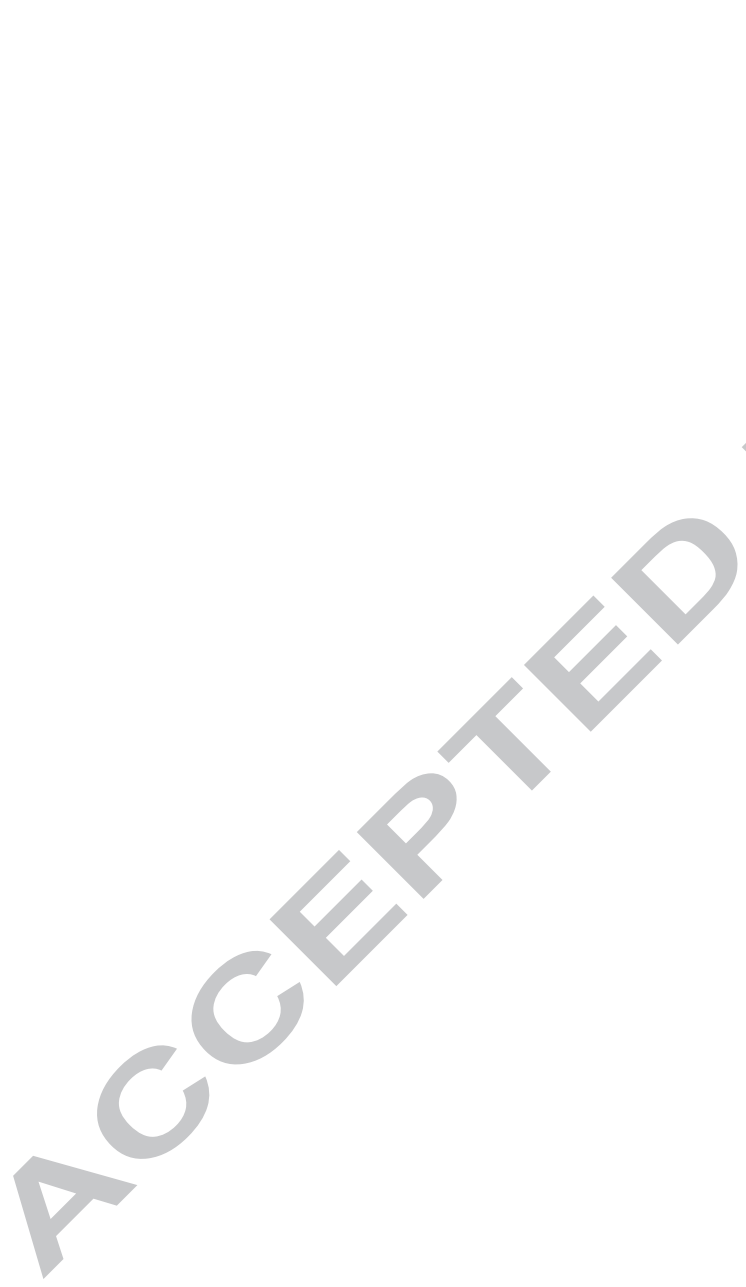

